\title{
Antibacterial and antifungal activity of extracts and exudates of the Amazonian medicinal tree Himatanthus articulatus (Vahl) Woodson (common name: sucuba)
}

\author{
Bianca Jorge Sequeira', Marcos Jose Salgado Vital', Adrian Martin Pohlit ${ }^{1,2}{ }^{+}$ \\ Isabel Costa Pararols², Glaucia Socorro Barros Caúper² \\ ${ }^{1}$ Universidade Federal de Roraima, Boa Vista, RR, Brasil '2Laboratório de Princípios Ativos da Amazônia, Coordenação de Pesquisas em \\ Produtos Naturais, Instituto Nacional de Pesquisa da Amazônia, Av. André Araújo 2936, 69060-001, Manaus, AM, Brasil
}

Himatanthus articulatus (Vahl) Woodson is a tree found in the northern Amazon savannahs (common name: sucuba) that is used in local Amerindian medicine. Leaf, bark and branch wood methanol extracts, sequentially obtained hexane, ethyl acetate and methanol extracts and latex were evaluated for antifungal and antibacterial activities against American Type Culture Collection (ATCC) and local clinical strains using the disc diffusion method. Methanol extracts and latex inhibited Candida albicans, leaf methanol extracts inhibited Staphylococcus aureus and Bacillus subtilis and bark methanol extracts inhibited B. subtilis. Active extracts inhibited the ATCC and clinical strains. Polar antifungal and antibacterial principles in latex and extracts are thought to be responsible for the inhibition.

Key words: Candida albicans - Staphylococcus aureus - Bacillus subtilis - Escherichia coli - Apocynaceae - Roraima

Promoting scientific research into traditional medicine can be a means of preventing the disappearance of the cultural practices of a people and provide a simple and locally accessible therapeutic alternative to local health authorities. In recent times, greater access to industrialized pharmaceuticals has, in general, been accompanied by a decline in medicinal knowledge and the use of plant-based remedies. However, in the Amazon Region, the medicinal use of products derived from plants by local communities continues to be a significant practice. Furthermore, many local indigenous populations depend exclusively on natural products for the treatment and cure of disease (Milliken 1995). In general, many widely-used plant-derived remedies from the Amazon have never been evaluated in a laboratory or clinical setting. Such investigations generate valuable knowledge on the potential of Amazon biodiversity (Carneiro et al. 2008).

Himatanthus articulatus (Vahl) Woodson (Apocynaceae) is a tree found in Panama, Colombia, Peru, Bolivia, Venezuela, Guyana, Suriname, French Guiana and in the savannah regions of the state of Roraima (RR), in the northern Brazilian Amazon (Milliken 1995, Wood et al. 2001, Mobot 2007). In Brazil, H. articulatus is known by the common name sucuba and is therapeutically one of the most widely-used medicinal plants in the northern Amazon Region. According to ethnobotanical sources, $H$. articulatus is medicinally used by the Macuxi, Maiongong, Taurepang and Ingarikó indigenous groups (Milliken 1995). Leaf and bark infusions are used as

Financial support: CNPq/PPG-7 557106/2005-2 +Corresponding author: ampohlit@inpa.gov.br Received 11 June 2008

Accepted 3 March 2009 anti-inflammatory agents, analgesics (Miranda et al. 2000), antimalarials (Milliken 1995), antitumor agents, vermifuges, purgatives (Persinos-Perdue \& Blomster 1978), antitussive agents (Elizabetsky \& Castilhos 1990) and are important agents in the treatment of blood parasites such as Trypanosoma cruzi and Leishmania donovani (Mesquita et al. 2005). Antitumor and aphrodisiac properties have been reported for the latex derived from sucuba, which is typically diluted in water and administered orally (Van den Berg 1984). According to Souza et al. (2004), plants belonging to the genus Himatanthus demonstrate a large spectrum of anti-bacterial activities. Also, sucuba is commonly sold for use as an antimicrobial agent in popular markets in RR. No previous investigation of the antibacterial or antifungal activity of $H$. articulatus is available in the literature, although antimicrobial activity has been reported for other Himatanthus spp. (Morel et al. 2006).

It is known that microorganisms frequently become resistant to conventional antimicrobial agents, so the utilization of natural antimicrobial agents could represent a low-cost alternative therapy for traditional communities from the Brazilian Amazon. Also, chemical studies of antimicrobial plant extracts could reveal new substances with potential usefulness as antimicrobial drugs or as models for the development of new drugs. Thus, the aim of the present work was to evaluate the antibacterial and antifungal potential of leaf, bark and branch wood extracts and the latex of $H$. articulatus against the growth of several human pathogenic bacterial and fungal strains.

According to statistical data available from the Laboratório Central de Roraima (LACEN), which is located in Boa Vista, the capital of RR, for the period of 2004-2007, Escherichia coli was responsible for $80 \%$ of the clinical cases of genital and urinary infections, Staphylococcus aureus was responsible for $90 \%$ of eye infections, pyodermitis septicemias and hospital infections and the fun- 
gus Candida albicans was the etiological agent in $70 \%$ of cutaneous and mucous membrane infections. These data from local clinics led us to conduct this screening study with the above-mentioned clinically relevant species. $B a$ cillus subtilis was used as a control strain.

The microorganisms used in this study were both standardized strains from institutional collections, as well as field isolates. Field isolates can sometimes have an advantage over standard strains in that they often reflect the contemporary genetic profile of microorganisms and fungi in the clinical or field setting. This genetic difference can be important for assessing the relevance of medicinal plants which should be active against field and standard strains. The standard bacterial strains used were: $S$. aureus ATCC (American Type Culture Collection) (12600), E. coli DAUFPE (Universidade Federal de Pernambuco)-ATCC (25922) and $B$. subtilis DAUFPE-ATCC (6633). The fungus strain used was $C$. albicans UFRGS (Universidade Federal de Rio Grande do Sul)-ATCC (0028L). For comparison, a field isolate of each bacterial and fungal species was obtained from samples of urine and infection-related secretions, obtained from patients receiving treatment at LACEN. All bacterial strains were cultured on nutrient agar and the fungus was cultured on Sabouraud agar and incubated at $36^{\circ} \mathrm{C}$ for $48 \mathrm{~h}$.

$H$. articulatus branches, bark, leaves and latex were collected on September 3, 2005 from two individual plants located on the Universidade Federal de Roraima campus, in Boa Vista. Identification was performed based on voucher specimens deposited at the INPA Herbarium in Manaus under the accession number 216.259. Latex was obtained in the field by swabbing the exudate from a bark incision with wetted cotton and was subsequently stored at $-19^{\circ} \mathrm{C}$.

Solvents were purified by fractional distillation before use. Dry, powdered plant components were continuously extracted in a soxhlet apparatus with methanol. Continuous extraction was also performed, first with hexane, then ethyl acetate and finally methanol, on another portion of plant materials to yield extracts of increasing polarity. After extraction, the solvents were removed by rotary evaporation and the resulting residues were further freeze-dried and stored at $-19^{\circ} \mathrm{C}$. The latex obtained directly from bark incisions in the procedure described above was freeze-dried $\left(-19^{\circ} \mathrm{C}\right)$.

The Kirby-Bauer disc diffusion method (Bauer et al. 1966) is based on the inhibition of microorganism growth on the surface of culture medium inoculated with test microorganisms (Koneman et al. 1999). This method was used to determine the rate of inhibition in the growth of bacteria and fungi by plant extracts and latex. Bacterial colonies were diluted in sterilized water to a turbidity of 0.5 on the MacFarland Scale. MuellerHinton agar plates were then inoculated by swabbing with the bacterial suspension. The fungi were diluted in sterilized water to the same turbidity as described above for bacteria and then inoculated onto Sabouraud agar plates. Each dry extract was dissolved in methanol using a micropipette and the resulting solutions were applied to blank filter paper discs $(6 \mathrm{~mm})$. The discs were then allowed to dry in an oven at $37^{\circ} \mathrm{C}$ for $48 \mathrm{~h}$ before being placed on the surface of the agar on each plate. The extracts were diluted in methanol and the resulting solutions were applied to discs. The evaporation of solvents resulted in the generation of discs with concentrations of 1.0, 0.5 and $0.25 \mathrm{mg}$ extract/disc. Similarly, latex was diluted in methanol and applied to the discs in the above-mentioned quantities. These discs were applied to inoculated agars in triplicate for determination of the minimum inhibitory concentrations, average inhibition halo diameters and standard deviations. The plates were incubated at $36^{\circ} \mathrm{C}$ for $24 \mathrm{~h}$ and the growth inhibition zones were recorded. The diameter $(12 \mathrm{~mm})$ of the inhibition halo of the commercial antibiotic vancomycin (30 $\mu \mathrm{g} / \mathrm{disc}$ ) (Lorian) was used as positive control for all test microorganisms used. Essentially the same procedure was employed to evaluate antifungal activity towards C. albicans, using vancomycin as positive control. As a means of standardizing and comparing results of antibacterial and antifungal screening of extracts, an extract with a bacterial or fungal inhibition zone $\geq 12 \mathrm{~mm}$ was considered to be active and an extract displaying an inhibition zone $\leq 6 \mathrm{~mm}$ (absence of inhibition zone) was considered inactive.

In general, screening of $H$. articulatus leaf, bark and branch wood extracts and latex revealed extractorganism-specific antibacterial and antifungal activities. Thus, all extracts [hexane, ethyl acetate, methanol (direct or sequential extraction) of all plant constituents] and latex were totally inactive against ATCC and clinical E. coli. Also, hexane and ethyl acetate extracts of all tested plant components were totally inactive against ATCC and clinical isolates of C. albicans, B. subtilis and $S$. aureus. Among the extracts, inhibition of bacterial and fungal growth was only observed for methanol extracts of $H$. articulatus prepared using sequential or direct extraction (Table). Leaf methanol extracts of $H$. articulatus inhibited $S$. aureus, bark and leaf methanol extracts were active against $B$. subtilis and all methanol extracts and latex displayed inhibitory activity against the fungal species, C. albicans. Latex exhibited antifungal activity, but not antibacterial activity.

Chi-square statistical analysis showed that there was no difference between the sensitivity of ATCC and clinical strains, nor was there a significant difference between tests performed at 0.5 and $1.0 \mathrm{mg}$ sample/disc. All active extracts and latex resulted in inhibitory minima greater than 0.25 and less than $0.5 \mathrm{mg} / \mathrm{disc}$. The only significant differences observed were between the inhibitory efficiencies of the methanol extracts and latex. The following decreasing order of inhibition could be established for leaf (44\%), bark (32\%) and branch wood $(16 \%)$ extracts, as well as latex $(8 \%)$.

The $H$. articulatus latex used in this study displayed antifungal properties and was obtained using the common method of swabbing incisions made in the bark with water, which is a highly polar solvent. The antifungal and antibacterial properties displayed by $H$. articulatus methanol extracts are also noteworthy given the high polarity of this solvent and its affinity for alkaloids, iridoids and terpenes, among others (Matos 1989). According to the phytochemical literature, many of these polar com- 
TABLE

Antibacterial and antifungal activities of latex, leaf bark and branch wood extracts of Himatanthus articulatus

\begin{tabular}{|c|c|c|c|c|c|c|c|c|c|c|c|c|c|c|}
\hline \multirow{5}{*}{$\frac{\text { Plant }}{\text { Part }}$} & & & \multicolumn{12}{|c|}{ Average inhibition zone diameters $(\mathrm{mm})^{a}$} \\
\hline & & & \multicolumn{4}{|c|}{ Candida albicans } & \multicolumn{4}{|c|}{ Bacillus subtilis } & \multicolumn{4}{|c|}{ Staphylococcus aureus } \\
\hline & & & \multicolumn{2}{|c|}{ ATCC } & \multicolumn{2}{|c|}{ Clinical } & \multicolumn{2}{|c|}{ ATCC } & \multicolumn{2}{|c|}{ Clinical } & \multicolumn{2}{|c|}{ ATCC } & \multicolumn{2}{|c|}{ Clinical } \\
\hline & \multicolumn{2}{|c|}{ Extract } & \multicolumn{4}{|c|}{ mg extract/disc } & \multicolumn{4}{|c|}{ mg extract/disc } & \multicolumn{4}{|c|}{ mg extract/disc } \\
\hline & Solvent & Process & 0.5 & 1.0 & 0.5 & 1.0 & 0.5 & 1.0 & 0.5 & 1.0 & 0.5 & 1.0 & 0.5 & 1.0 \\
\hline \multirow[t]{2}{*}{ Leaf } & $\mathrm{MeOH}$ & direct & 17 & 19 & 16 & 18 & 10 & 12 & 10 & 12 & 14 & 16 & 13 & 15 \\
\hline & $\mathrm{MeOH}$ & sequential & 13 & 14 & 13 & 15 & 13 & 14 & 14 & 15 & 13 & 14 & 13 & 15 \\
\hline \multirow[t]{2}{*}{ Bark } & $\mathrm{MeOH}$ & direct & 15 & 17 & 13 & 16 & 15 & 17 & 15 & 16 & - & - & - & - \\
\hline & $\mathrm{MeOH}$ & sequential & 14 & 15 & 15 & 17 & 14 & 15 & 15 & 17 & - & - & - & - \\
\hline \multirow[t]{3}{*}{ Branch } & $\mathrm{MeOH}$ & direct & 14 & 15 & 15 & 16 & - & - & - & - & - & - & - & - \\
\hline & $\mathrm{MeOH}$ & sequential & 15 & 17 & 14 & 15 & - & - & - & - & - & - & - & - \\
\hline & Latex & swab & 14 & 16 & 13 & 15 & - & - & - & - & - & - & - & - \\
\hline
\end{tabular}

$a$ : averages of triplicate assays of each sample. The average inhibition zone diameter of positive control vancomycin $(30 \mu \mathrm{g} /$ disc) was $12 \mathrm{~mm}$; -: inactive (inhibition diameter $\leq 6 \mathrm{~mm}$ ). Only extracts presenting inhibition towards at least one microorganism are presented.

pounds have been reported in Himatanthus spp. (AbderKadel et al. 1997, Veloso et al. 1998, Wood et al. 2001, Souza et al. 2004, Mesquita et al. 2005). Furthermore, the fact that low (hexane) and medium (ethyl acetate) polarity extracts displayed no inhibitory activity whatsoever further points to the probable polar nature of antifungal and antibacterial substances present in $H$. articulatus.

$E$. coli strains were the only Gram-negative bacteria used in this study and were resistant to all extracts and latex. This resistance may be explained by structural differences in the cell membranes of Gram-negative and Gram-positive bacteria. In general, Gram-negative bacteria have two cell membranes while Gram-positive bacteria have only one. Thus, the double membrane in Gram-negative bacteria is associated with lower membrane penetration by extracts or other substances and a greater difficulty for bioactive substances to reach active sites, as compared to Gram-positive bacteria (Koneman et al. 1999).

\section{ACKNOWLEDGEMENTS}

To Reinaldo Imbrozio Barbosa (INPA), for help in the field, collection of plant materials and identification. Collection and transport of plant materials was performed with authorization of IBAMA (process 02025.004729/05-71; license 003/2006 COMON).

\section{REFERENCES}

Abder-Kadel MS, Wisse J, Evans R, Werff HV, Kingston D 1997. Bioactive iridoids and a new lignan from Allamanda cathartica and Himatanthus falax from the Suriname rainforest. J Nat Prod 60: 1294-1297.

Bauer AW, Kirby WM, Sherris JC, Turck M 1966. Antibiotic susceptibility testing by a standardized single disk method. Am J Clin Pathol 45: 493-496.

Carneiro ALB, Teixeira MFS, Oliveira VMA, Fernandes OCC, Cauper GSB 2008. Screening of Amazonian plants from the Adolpho Ducke Forest reserve, Manaus, state of Amazonas, Brazil, for antimicrobial activity. Mem Inst Oswaldo Cruz 103: 31-38.
Elizabetsky E, Castilhos C 1990. Plants used as analgesics by Amazonian caboclos as a basis for selecting plants for investigation. Int $J$ Crude Drug Res 28: 309-320.

Koneman EW, Allen SD, Janda WM, Schreckenberg PC, Winn WC 1999. Diagnóstico microbiológico, 5th ed., Panamericana, Buenos Aires, p. 65-78.

Matos FJA 1989. Plantas medicinais. Guia de seleção e emprego de plantas usadas em fitoterapia no Nordeste do Brasil, EMBRAPA, Fortaleza, p. 29-30.

Mesquita ML, Desrivot J, Bories C, Fournet A, Paula JE, Grellier P, Espindola LS 2005. Antileishmanial and trypanocidal activity of Brazilian cerrado plants. Mem Inst Oswaldo Cruz 100: 783-787.

Milliken W 1995. Plants used in the treatment of malaria in Roraima state - Preliminary report, Royal Botanic Garden, Kew, 67 pp.

Miranda ALP, Silva JRA, Rezende CM, Neves JS, Parrini SC, Pinheiro MLB, Cordeiro MC, Tamborini E, Pinto AC 2000. Antiinflammatory and analgesic activities of the latex containing triterpenes from Himatanthus sucuuba. Planta Med 66: 284-286.

Mobot 2007. Missouri Botanical Gardens. Available from: mobot.mobot.org/cgi-bin/search_vast. [Accessed: Feb 11].

Morel AF, Graebner IB, Porto C, Dalcol II 2006. Study on the antimicrobial activity of Himatanthus sucuba. Fitoterapia 77: 50-53.

Persinos-Perdue G, Blomster RN 1978. South American plants. III. Isolation of fulvoplumerin from Himatanthus sucuuba (M. Arg.) Woodson (Apocynaceae). J Pharm Sci 67: 1322-1323.

Souza WM, Stinghen AEM, Santos CAM 2004. Antimicrobial activity of alkaloidal fraction from barks of Himatanthus lancifolius. Fitoterapia 75: 750-753.

Van den Berg MA 1984. Ver-o-peso: the ethnobotany of an Amazonian market. In: GT Prance, JA Kallunk, Advances in economic botany. Ethnobotany in the Neo Tropics, New York Botanical Garden, New York, p. 140-149.

Veloso MP, Nagem TA, Oliveira TT 1998. $\beta$-Dehidroplumericinic acid from Himatanthus phagedaenicus. Biochem Syst Ecol 27: 669-671.

Wood CA, Lee K, Vaisberg EJ, Kingston DGI, Neto CC, Hammond GB 2001. A bioactive spirolactone iridoid and triterpenoids from Himatanthus sucuuba. Chem Pharm Bull (Tokyo) 49: 1477-1478. 